Physical Therapy Journal of Indonesia (PTJI) 2020, Volume 1, Number 2: 26-28

E-ISSN : 2722-6034; P-ISSN : 2722-0125

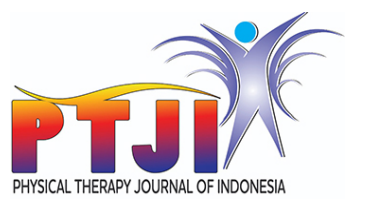

\title{
Online Game Duration Associated to Neck Functional Disability in Esports Athletes
}

\author{
I Kadek Dwi Widhi Dharma ${ }^{1 *}$, Ni Wayan Teza Andika ${ }^{1}$, Ni Luh Anita Chandra Dewi', \\ I.A. Pascha Paramurthi ${ }^{1}$, Ida Kurniawati ${ }^{2}$
}

\begin{abstract}
Background: Online games are a form of online recreational activity that is very easy to access and can be played at any time. Playing online games for a long time can cause several disturbances, such as a neck's functional disorder. This study aimed to determine the relationship between the duration of playing online games and Neck Functional Disability among esports.

Methods: This is a cross-sectional study which was conducted in November-December 2019. The sample in this study is recruited from the esport community in Denpasar-Bali, with 62 respondents. Results: The data from 62 people, the range of active esport activity duration was 12-24 months, and the duration of active playing games per day was $5-10$ hours. Most respondents aged 18-21 years

respondents (24.2\%). More male respondents were 42 respondents (67.7\%) than 20 female respondents (32.3\%). Respondents in the 13-18 months category were 28 respondents (45.2\%). Category 19-24 months as many as 16 respondents (28.8\%), and category 6-12 months as many as 18 respondents (29.0\%). There were 24 respondents in the neck disability categories (38.7\%), 18 in the severe category (29.0\%), and 20 in the mild category (32.3\%).

Conclusion: Regardless of this study's limitations, respondents who participated actively in sports for a long period was associated with neck disabilities. Respondents who actively play online games for13-18 months and 19-24 months are associated with moderate and severe neck disabilities.
\end{abstract} were 47 respondents $(75.8 \%)$, and at the age of $22-25$ years were 15

Keywords: esport, duration, neck disabilities.

Cite this Article: Dharma, I.K.D.W., Andika, N.W.T., Dewi, N.L.A.C., Paramurthi, A.A.P., Kurniawati, I. 2020. Online Game Duration Associated to Neck Functional Disability in Esports Athletes. Physical Therapy Journal of Indonesia 1(2): 26-27.
'Department of Physical Therapy, Universitas Bali International ${ }^{2}$ Master Student at Graduate Institute of Biomedical Informatics, College of Medical Science and Technology, Taipei Medical University, Taipei, Taiwan
*Corresponding author: I Kadek Dwi Widhi Dharma; Department of Physical Therapy, Universitas Bali International; widhidharma9@gmail.com
Received : 2020-06-28 Accepted : 2020-10-28 Published: 2020-12-01

\section{INTRODUCTION}

Technological development in the entertainment field is increased sharply. The impacts of this phenomenon is signed by the online game that played by all circle of society which is millennial generation as a dominant player. ${ }^{1}$ Online games not only a part of the entertainment field but as a part of job opportunities for society with all range of ages as esports athletes. ${ }^{2}$

As one of the islands with the highest tourist destination in Indonesia, Bali also has great potential to become one of the esport community players progressively. However, the long duration of sedentary behavior activities, such as playing online games, can cause the body's physical and mental disturbances. ${ }^{3}$ Besides, the player's body's improper position when playing esports will cause various kinds of physical problems, such as structural and functional disturbances. The consequences of esports activity with long term duration and less physical activities are a pain in the body and factors associated with neck disability. ${ }^{4}$

This study was conducted to understand whether the duration of playing online games associated with the neck disability in esport athletes. The

\section{METHODS}

This is a cross-sectional study which was conducted in November-December 2019. The sample in this study is recruited from the esport community in Denpasar-Bali, with 62 respondents. We categorized these participants into three groups based on play duration, which was 6-12 months, 13-18 months, and 19-24 months groups.

The neck disability index (NDI) is a selfreported questionnaire to evaluate the neck-specific disability. ${ }^{5}$ This questionnaire contains of 10 items concerning to pain levels and activities of daily living, including personal care, lifting, reading, headaches, concentration, work status, driving, sleeping, and recreation. The rating categories from the NDI are categorized into mild (0-20\%), moderate (20-40\%), severe (40-60\%), and paralyzed disability (60-80\%). A demographic questionnaire was provided to collect the respondents' characteristics such as age, gender, the duration of playing the game online, and the duration of duration from the first time as a game online player until the recruitment date. 


\section{RESULTS}

Of the 62 respondents, the range of duration for active esport was 6 to 24 months. The duration of active playing games per day was 5 to 10 hours.

Table 1 showed that most respondents were aged 18-21 years, as many as 47 respondents $(75.8 \%)$, and at the age of $22-25$ years as many as 15 respondents (24.2\%). More male respondents were 42 respondents (67.7\%) than 20 female respondents $(32.3 \%)$. There were 28 respondents (45.2\%) included in the category of 13-18 months, 16 respondents in the $19-24$ month (28.8\%), and 18 respondents (29.0\%) in the 6-12 months as active esport players. There were 24 respondents (38.7\%) who had an NDI score of the moderate category, 18 respondents $(29.0 \%)$ of severe category, and 20 respondents $(32.3 \%)$ of the mild category.

In Table 2, of 62 respondents, 24 respondents (38.7\%) had a moderate NDI score $(\mathrm{P}=0.002)$. Based on the duration of playing, 11 respondents (61.1\%) in 6-12 months obtained the mild NDI score, 14 (50.0\%) respondents in 13-18 months obtained the moderate NDI score, and 8 respondents (50\%) in 19-24 months obtained the severe NDI score.

Table 1. Characteristics of respondents in the active online game esport

\begin{tabular}{lc}
\hline \multicolumn{1}{c}{ Characteristics } & $\boldsymbol{n}(\%)$ \\
\hline Age (years) & \\
$18-21$ & $47(75,8)$ \\
$22-25$ & $15(24,2)$ \\
Gender & \\
Male & $42(67,7)$ \\
Female & $20(32,3)$ \\
Duration (months) & \\
$6-12$ & $18(29,0)$ \\
$13-18$ & $28(45,2)$ \\
$19-24$ & $16(25,8)$ \\
\hline
\end{tabular}

\section{DISCUSSION}

Based on the study results, there was a relationship between the duration of playing games and the emergence of pain complaints felt by respondents in this study. This complaint was felt due to an excessive load placed on the neck muscles during playing the online game. ${ }^{6}$ The loading on the respondents' neck muscles in this observation might differ, considering the different durations of playing the game.

The duration with the 6-12 months category has a higher prevalence of mild pain. This occurred possibly because the duration of the loading applied to the neck muscles was a static contraction, which produced less pain, and the tension and loading were still in a tolerable period of time. The symptoms that usually felt in the neck muscles include intermittent pain, tightness, or spasm, yet these would not interfere with the daily activities. ${ }^{7}$ Playing a duration of 13-18 months had a moderate prevalence of pain, possibly caused by a longer and larger loading on the neck muscles than 6-12 months that caused muscle tightness that refers to pain. The pain interfered with daily activities, but it usually still might be controlled. ${ }^{8}$ These study findings proved that the longer the duration of playing online games, the higher possibility of getting neck disabilities.

Duration with the category 19-24 months has the highest prevalence of neck disabilities. This possibly resulted in functional disorders in the neck that interfere with daily activities with obvious neck pain. One of the most common causes of neck disability was the ergonomic aspect of the body position when playing online games. The players usually had a poor body position while playing online games for a long time, such as forward head and rounded shoulders, which caused high loading on the muscles from the back to the neck. This position might trigger greater pain because of muscle fatigue on the sternocleidomastoid and anterior scalene muscles. ${ }^{9}$

$n$, number of respondents

Table 2. Chi-square test between the duration of active esport and neck disabilities

\begin{tabular}{|c|c|c|c|c|c|}
\hline \multirow{2}{*}{$\begin{array}{l}\text { Duration of active } \\
\text { esport (months) }\end{array}$} & \multicolumn{4}{|c|}{ Neck disability index } & \multirow{2}{*}{$P$-value } \\
\hline & $\begin{array}{l}\text { Mild } \\
n(\%)\end{array}$ & $\begin{array}{c}\text { Moderate } \\
n(\%)\end{array}$ & $\begin{array}{c}\text { Severe } \\
n(\%)\end{array}$ & $\begin{array}{l}\text { Total } \\
n(\%)\end{array}$ & \\
\hline $6-12$ & $11(61.1)$ & $5(27.8)$ & $2(11.1)$ & $18(100)$ & 0.002 \\
\hline $13-18$ & $6(21.4)$ & $14(50.0)$ & $8(28.6)$ & $28(100)$ & \\
\hline $19-24$ & $3(18.8)$ & $5(31.2)$ & $8(50.0)$ & $16(100)$ & \\
\hline
\end{tabular}

$n$, number of respondents 
Previous study explained that sternocleidomastoid and anterior scalene muscles fatigability increased because of the inactivation of the deep cranio-cervical flexor muscles. ${ }^{10}$ The training for the deep cranio-cervical flexor muscles using the low to moderate load showed to be effective for minimizing the activation of sternocleidomastoid and anterior scalene muscles. ${ }^{11}$ However, another study have found that the endurance-strength regime training was more effective than cranio-cervical training for reducing the mean spectral frequency of electromyography on sternocleidomastoid and anterior scalene muscles in a low and moderate intensity training, although both of these interventions improved the pain and neck disabilities. ${ }^{9}$

This study has several limitations. Firstly, this study results could not be generalized to the esports athletes in Indonesia. Different patients' characteristics, such as the athletes' competition level and socioeconomic factors, possibly confounded this study results. Secondly, this study results might not be able to describe any cause and effect relationship. We were not able to perform any prospective study design because of the authors' time limitation.

\section{CONCLUSION}

Regardless of this study's limitations, respondents who participated actively in sports for a long period was associated with neck disabilities. Respondents who actively play online games for 13-18 months and 19-24 months are associated with moderate and severe neck disabilities. We suggested using a prospective or randomized control trial study design to improve the evidence's quality in the future study.

\section{CONFLICT OF INTEREST}

No conflict of interest to declare in this study.

\section{FUNDING}

Not applicable.

\section{AUTHOR CONTRIBUTIONS}

IKDWD conceived the study design, data collection, data analysis, and drafted the manuscript; NWTA,
NLACD, and IAPP collected the data and drafted the manuscript, ID performed the data analysis and drafted the manuscript.

\section{REFERENCES}

1. Riki Y. Pengaruh Game Online Terhadap Perilaku Remaja Studi Kasus: 5 orang remaja pelaku Game Online di Kelurahan Air Tawar Barat, Kecamatan Padang Utara, Kota Padang: Universitas Andalas; 2011.

2. Brock T. Roger Caillois and e-sports: On the problems of treating play as work. Games and Culture. 2017;12(4):32139.

3. Triyantama AR, Santoso E. Model Komunikasi Virtual Pemain Game PUBG MOBILE Menggunakan Studi Etnografi Virtual Pada Kelompok Game PUBG MOBILE RPX E-Sport. MEDIUM. 2019;7(1):53-70.

4. Koteng MSJ, Ratu JM, Berek NC. Hubungan Faktor Risiko Individu dan Ergonomi dengan Kejadian Nyeri Punggung Bawah (Low Back Pain) pada Pengguna Game Online. Media Kesehatan Masyarakat. 2019;1(1):15-20.

5. Vernon H, Mior S. The Neck Disability Index: a study of reliability and validity. J Manipulative Physiol Ther. 1991.

6. Gugliotti M. Contribution of aberrant postures to neck pain and headaches in esport athletes. Spine (Phila Pa 1976). 2018;19(12):1307-9.

7. Lindberg L, Nielsen SB, Damgaard M, Sloth OR, Rathleff MS, Straszek CL. Musculoskeletal pain is common in competitive gaming: a cross-sectional study among Danish esports athletes. BMJ Open Sport \& Exercise Medicine. 2020;6(1):000799.

8. Zwibel H, DiFrancisco-Donoghue J, DeFeo A, Yao S. An Osteopathic Physician's Approach to the Esports Athlete. The Journal of the American Osteopathic Association. 2019;119(11):756-62.

9. Falla D, Jull G, Hodges P, Vicenzino B. An endurancestrength training regime is effective in reducing myoelectric manifestations of cervical flexor muscle fatigue in females with chronic neck pain. Clin Neurophysiol. 2006;117(4):828-37.

10. Falla D, Rainoldi A, Merletti R, Jull G. Myoelectric manifestations of sternocleidomastoid and anterior scalene muscle fatigue in chronic neck pain patients. Clin Neurophysiol. 2003;114(3):488-95.

11. Jull G, Trott P, Potter H, Zito G, Niere K, Shirley D, et al. A randomized controlled trial of exercise and manipulative therapy for cervicogenic headache. Spine (Phila Pa 1976). 2002;27(17):1835-43.

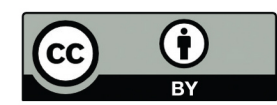

This work is licensed under a Creative Commons Attribution 